\title{
NEIZVJESNA DEMOGRAFSKA BUDUĆNOST HRVATSKE - IZUMIRANJE I SUPSTITUCIJA STANOVNIŠTVA ILI POPULACIJSKA REVITALIZACIJA...?
}

Stjepan ŠTERC, Monika KOMUŠANAC

Prirodoslovno-matematički fakultet, Zagreb

UDK: $314.87(497.5)$

$314.15(497.5)$

Pregledni rad

Primlieno: 21. 9. 2011

Temelini cilj i svrha rada jest potvrditi nemogućnost revitalizacije bez ozbiline, odgovorne i ciljane populacijske politike, procijeniti demografski revitalizacijski potencijal (koji uza sve negativnosti demografske slike Hrvatske još uvijek postoji) i postaviti demografsku problematiku u temelj razvoja i opstanka suvremene Hrvatske. Sve su analize potvrdile izrazitu negativnost svih parametara i nemogućnost zaustavljanja negativnih procesa bez ozbilinije intervencije države stimulativnom populacijskom politikom i uključivanjem hrvatske dijaspore u gospodarske, političke i revitalizacijske procese u zemlij. Metodologijski je pristup usmjeren samo na osnovne sadržaje, procese, veze i odnose, kako bi se kroz njih pokazala dramatičnost vremena i stanja u kojem se Hrvatska nalazi. Posebno su primjenjivane spoznaje o zakonitostima što ih stanovništvo razvija u prostoru. Najvažniji rezultat razmatranja problematike jest spoznaja kako Hrvatska, usprkos dugogodišnjim negativnim trendovima svih demografskih procesa, još uvijek ima demografski potencijal u zemlii, a posebno u dijaspori, i može poticajnom populacijskom politikom zaustaviti izumiranje i naglo starenje ukupne populacije te pokrenuti revitalizaciju svojega stanovništva u interesu gospodarskoga razvoja i vlastite budućnosti.

Ključne riječi: prirodni pad, depopulacija, starenje, izumiranje, revitalizacija

$\triangle \quad$ Stjepan Šterc, Sveučilište u Zagrebu, Prirodoslovno-matematički fakultet, Geografski odsjek, Marulićev trg 19/2, 10000 Zagreb, Hrvatska. E-mail: sterc@geog.pmf.hr 
Demografska budućnost Hrvatske poprilično je neizvjesna s obzirom na dugotrajne negativne trendove, izgubljenu demografsku prošlost, duboku starost ukupne populacije, nizak fertilitet mjeren totalnom stopom fertiliteta, dugotrajni prirodni pad stanovništva, pojavu sekundarne negativne migracijske bilance, djelovanje posebnih faktora na razvoj hrvatske populacije itd. itd. te dolaska u razvoju do ključne razdjelnice između nastavka izumiranja ukupnoga stanovništva i moguće populacijske revitalizacije. Poseban je to istraživački interes s obzirom na to da je stanovništvo temelj svih prostornih, regionalnih, gospodarskih, društvenih i inih planiranja, osnovni prostorni resurs i potencijal te u svakoj zemlji nacionalni strateški interes. Poznavajući opće trendove do početka devedesetih, postavljena je već u samom naslovu rada temeljna dilema demografske budućnosti Hrvatske - neizvjesnost kao objektivno moguća varijanta i revitalizacija kao potencijalna mogućnost - s mnogo nepoznanica u toj budućnosti. Stoga je zadatak i obveza znanstvene i ostale javnosti, osim intenzivnih i izrazito znanstveno utemeljenih analitičkih pristupa i istraživanja specifične demografske problematike $\mathrm{RH}$, pokazati i dokazati $\mathrm{u}$ sinteznom pristupu smjer i intenzitet promjena, njihovu uzročno-posljedičnu povezanost i ponuditi rješenja kako populacijska budućnost Hrvatske ne bi bila potpuno neizvjesna. Ne prihvaćamo pritom standardna mišljenja koja se vrlo često potkrepljuju djelomičnim istraživanjima što zadovoljavaju statističke, formalne, predmetne, metodološke i ine forme objavljivanja radova, u kojima je tehnički pristup pretpostavljen spoznajnom i logičkom, u razumijevanju složenosti postojeće i povijesne prostorno-vremenske stvarnosti i njezine projekcije u budućnosti. Razumijevanje hrvatskoga demografskog razvoja ne može se temeljiti samo na često upitnim statističkim bilježenjima ni na vidljivim strukturama, s obzirom na to da su relacije stanovništva u društvu i prostoru stohastičke, a nerijetko nevidljive i nemjerljive. Zato, između osta$\log$, treba razumjeti filozofiju i logiku prostora iz koje izlaze zakonitosti prostorno-vremenskih struktura i procesa.

PREDMET ISTRAŽıVANJA

Razmotrit će se osnovni parametri koji pokazuju i potvrđuju bitne i temeljne zakonitosti izgubljene hrvatske demografske prošlosti i vrlo neizvjesne budućnosti, s obzirom na to da niz ostalih pokazatelja, bez obzira na složenost postupka dokazivanja, zapravo potvrđuju manje-više isto. Posebno će se istaknuti strateško značenje planiranja razvitka stanovništva i revitalizacije $u$ funkciji ciljane radne snage za razvoj gospodarstva, za regionalni razvoj te za razvoj društva općenito i očuvanja strateških nacionalnih demografskih vrijednosti. Osnovne 
DRUŠ. ISTRAŽ. ZAGREB GOD. 21 (2012), BR. $3(117)$

STR. $693-713$

ŠTERC, $\mathrm{S}$., KOMUSSANAC, M.: NEIZVJESNA... kategorije i pokazatelji razmotreni su kroz opće kretanje stanovništva kao kompleksni pokazatelj u 63 godine i starenje ukupnoga stanovništva kroz 17 godina, s tim da su zadnje godine $\mathrm{u}$ nizovima procijenjene $\mathrm{u}$ skladu s trendovima metodom matematičke ekstrapolacije, a u slučaju zadnjega popisa stanovništva iz 2011. godine uzeti su prvi rezultati koje je Državni zavod za statistiku objavio na početku srpnja 2011. godine. Analizirani su tako opće kretanje stanovništva i starenje, s obzirom na to da sadrže važne komponente kao što su ukupno međupopisno prirodno kretanje stanovništva, tzv. gruba migracijska bilanca kao razlika između međupopisne promjene i ukupnoga međupopisnog kretanja, a u procesu starenja pokazatelji odnosa velikih dobnih skupina koje su među ključnima za demografski i revitalizacijski potencijal Hrvatske. Oba ova kompleksna pokazatelja istodobno upućuju na izgubljenu demografsku prošlost i složenu i neizvjesnu budućnost Hrvatske.

Posebno će se razmotriti i promišljati te polemizirati s uobičajenim stavovima u domaćoj literaturi o očekivanom demografskom razvoju Hrvatske u okviru općeprihvaćene teorije demografske tranzicije, kao o nečem što je bila društveno-gospodarska i povijesna nužnost, te o potencijalu fertilnoga kontingenta ženskoga stanovništva kao mogućoj pretpostavci revitalizacije, za koji se u znanstvenim krugovima tvrdi da ne postoji u domicilnom ili stalnom stanovništvu Hrvatske. Obje su se hipoteze kroz radove znanstveno dokazivale i činile su paravan razumijevanja i prihvaćanja izrazito loše opće demografske slike Hrvatske, svjesno zanemarujući velike posebnosti njezina demografskog (i ne samo demografskog) razvoja, koji je u velikoj mjeri odredio, obilježio, usmjerio i, gotovo bi se moglo reći, determinirao današnju nepovoljnu opću demografsku sliku Hrvatske, u kojoj prevladava izumiranje ukupnoga stanovništva te polako i sigurno pražnjenje hrvatskoga prostora.

\section{DOSADAŠNJA ISTRAŽIVANJA}

Naslovnom problematikom bavili su se u prvom redu domaći autori s raznih aspekata i mjerila struka kojima pripadaju, a u radu je razmatran model izumiranja stanovništva u okviru tipizacije općega kretanja stanovništva, analizirajući pritom demografske parametre relevantne za izračunavanje ukupnoga i prirodnoga kretanja stanovništva između dva popisa kroz tzv. grubu migracijsku bilancu (prvi put i za popis 2011 .) ${ }^{1} \mathrm{i}$ radove koji izravno i neizravno $u$ tom razdoblju razmatraju tu problematiku. U prvu skupinu radova možemo ubrojiti sve radove koji izravno istražuju ukupni razvoj, depopulaciju i mogućnost revitalizacije (Friganović, 1984.; Gelo i sur., 2005.; La- 
DRUŠ. ISTRAŽ. ZAGREB GOD. 21 (2012)

BR. 3 (117)

STR. 693-713

ŠTERC, $\mathrm{S}$.

KOMUŠANAC, M. NEIZVJESNA...
1992.; Šterc i Crkvenčić, 1996.; Wertheimer-Baletić, 1989., 1992.b, 2004.; Živić, 2003., 2008.; Živić, Pokos i Turk, 2005.) Uglavnom su svi autori potvrdili da Hrvatska ima nepovoljne demografske pokazatelje i trendove i da ide prema depopulaciji i prirodnom padu stanovništva te da je za budućnost Hrvatske potrebna odgovarajuća populacijska revitalizacija i populacijska politika, ali bez konkretnijega modeliranja revitalizacije.

U drugu skupinu mogu ući radovi koji razmatraju bilanciranje prostorne pokretliivosti stanovništva i kontingentske potencijale (Akrap, 2011.; Akrap i Čipin, 2011.; Akrap i sur., 2003.; Čipin, 2011.; Gelo, 1999., 2004.; Gelo i sur., 2011.; Lajić i Šterc, 1990.a; Oliviera-Roca, 1990.), iz kojih se može potvrditi prevladavajuća pojava negativne migracijske bilance $u$ većini općina Hrvatske i smanjivanje fertilnih kontingenata stanovništva, važnih za reprodukciju ukupnoga stanovništva.

Iz radova navedenih autora može se zaključiti da je $\mathrm{Hr}$ vatskoj potrebna odgovarajuća populacijska politika, pa bismo u treću skupinu radova mogli ubrojiti radove koji se bave modelima populacijske politike Hrvatske (Friganović i Šterc, 1993.; Wertheimer-Baletić, 2000., 2004., 2005.). Ta su istraživanja rezultirala prijedlozima stimulativne populacijske politike za Hrvatsku u samim radovima, a nešto kasnije i u Nacionalnom programu demografskog razvitka, prihvaćenim u Saboru Republike Hrvatske 18. siječnja 1996. godine (tiskan 1997.).

Procjene demografske budućnosti izumiranja ili potencijalne revitalizacije moraju se zasnivati i na projekcijama stanovništva, koje čine četvrtu skupinu radova (Grizelj, 2005.; Nejašmić i Mišetić, 2004.; Mrđen, 2005.; Živić, Pokos i Mišetić, ur., 2005.). Posebno je nužno naglasiti da ni jedna projekcija nije uključivala moguću supstituciju stanovništva kao očekivanu varijantu nakon dužega procesa depopulacije. Kako su ratovi najveća društvena i demografska destrukcija i bitno usmjeravaju demografska poslijeratna kretanja, nužno je bilo razmotriti i demografske posljedice agresije na Hrvatsku na početku 1990-ih kao petu skupinu radova (Śterc i Pokos, 1993.; Živić i Pokos, 2004.) i kroz njih potvrditi intenziviranje negativne opće demografske slike RH. U šestu skupinu razmatranih radova možemo ubrojiti opće teorijsko-koncepcijske pristupe primjenjive i u ovom istraživanju (Friganović, 1966., 1983.; Šterc, 1986.; Wertheimer-Baletić, 1982., 1992.a) kao polazište razumijevanja općih zakonitosti u ranijim razdobljima i postavljanja ključnih pretpostavki.

\section{OSNOVNE HIPOTEZE}

Dosadašnje znanstveno-istraživačko i predavačko iskustvo, razvijena spoznaja o zakonitostima i modelima demografskog razvoja Hrvatske, razmotreni relevantni radovi i analiza statističkih podataka potvrđuju nam da je za ovu problematiku u današnjim hrvatskim gospodarskim, znanstvenim, društve- 
DRUŠ. ISTRAŽ. ZAGREB GOD. 21 (2012), BR. 3 (117)

STR. $693-713$

ŠTERC, $\mathrm{S}$ KOMUSSANAC, M.: NEIZVJESNA. nim, političkim, geopolitičkim, međunarodnim i razvojnim uvjetima nužno postaviti hipoteze koje izravno problematiziraju ključne demografske postavke već standardizirane u domaćoj literaturi, prema kojima je demografski razvoj Hrvatske očekivan, logičan, standardno uvjetovan i na koji se ne može posebno utjecati.

H 1 Demografski razvoj Hrvatske u 20. i 21. stoljeću nije se odvijao u okviru teorije demografske tranzicije niti se može samo njome objasniti.

H 2 Izumiranjem ukupnoga stanovništva u Hrvatskoj stvaraju se pretpostavke za prostornu supstituciju njezine populacije.

H 3 Fertilni kontingent ženskoga stanovništva u dobi najvećeg rađanja (od 20 do 39 godina) danas je isti kao $\mathrm{i}$ prije 10 godina i nije jedini faktor izrazitoga smanjivanja rodnosti.

H 4 Revitalizacijski modeli stanovništva Hrvatske još se uvijek mogu postavljati prema domicilnoj populaciji.

H 5 Hrvatska potencijalna demografska osnova moguća je i u dijaspori, koju sve emigracijske zemlje smatraju svojim bogatstvom.

\section{IZUMIRANJE STANOVNIŠTVA}

Izumiranje stanovništva određuje razlika između međupopisne promjene ukupnoga stanovništva i ukupnoga prirodnog kretanja stanovništva u međupopisnom razdoblju. Pri tome je prirodno kretanje negativno, međupopisna promjena još negativnija, a migracijska bilanca također negativna. Prisutna je depopulacija, pa je opća negativnost demografske slike potpuna. Potraje li izumiranje stanovništva dulje, npr. u razdoblju jednakom ili duljem od dva međupopisna razdoblja, pogotovo kod malih populacija, neizvjesnost revitalizacije jest očekivana. Kako su te populacije u pravilu u prostorima u kojima čitav kompleks geografskih faktora negativno utječe na useljavanje, a autohtono je stanovništvo iseljavano u duljem razdoblju, ostarjelo i u pravilu bez reprodukcijskoga i revitalizacijskoga potencijala, jasno je da takve populacije u budućnosti očekuje biološki nestanak, bez obzira na prostorne, regionalne, demografske, gospodarske i ine planove i strategije. Takvu budućnost očekuje tri četvrtine prostora Hrvatske, koji su u pravilu izvangradski, brdsko planinski, izolirani ... i u kojima su svi demografski pokazatelji negativni, a opća demografska slika porazna (Friganović, 1984.; Šterc, 1984.; Lajić i Sterc, 1990.b; Wertheimer-Baletić, 2004.; Živić, 2008.). Slični su trendovi već na početku devedesetih počeli zahvaćati i grad- 
DRUŠ. ISTRAŽ. ZAGREB GOD. 21 (2012), BR. 3 (117)

STR. 693-713

ŠTERC, $S$. KOMUŠANAC, M.: NEIZVJESNA...

(1) TABLICA 1

Međupopisna promiena ukupnoga noga kretanja i tzv. grube migracijske bilance te tipovi općega kretanja stanovnišstva Hrvatske od 1948. do 2011 . godine 3 stanovništva, prirod-

ske prostore, a tijekom devedesetih i na početku 21. stoljeća još su dodatno poprimili negativna obilježja potencirana agresijom na $\mathrm{RH}$, razorenim gospodarstvom, velikom nezaposlenošću i općim nepovoljnim stanjem u društvu bez kriterija i vrijednosti. Ukupno stanovništvo RH ne ubrajamo u male populacije $u$ analitičkom smislu, a još uvijek ni u populaciju koja biološki nestaje, s obzirom na ukupni hrvatski demografski potencijal i potencijal hrvatskoga nacionalnog teritorija mjeren položajem, sadržajima, značenjem, atraktivnošću mediteranske obale i slično, koji može ubuduće biti privlačna snaga imigracijske revitalizacijske varijante. Zato je važno razmotriti tipizaciju općega kretanja stanovništva i promjene tipova po međupopisnim razdobljima, kako bi se mogla realnije razumjeti hrvatska demografska budućnost (Tablica 1).2

\begin{tabular}{|c|c|c|c|c|c|c|c|c|}
\hline \multirow{2}{*}{$\begin{array}{l}\text { Međupo- } \\
\text { pisno } \\
\text { razdoblje }\end{array}$} & \multirow{2}{*}{$\begin{array}{l}\text { Broj } \\
\text { stanovnika u } \\
\text { 1. i 2. popisu }{ }^{1}\end{array}$} & \multicolumn{2}{|c|}{$\begin{array}{l}\text { Promjena } \\
\text { broja stanovnika } \\
\text { između dva popisa }\end{array}$} & \multicolumn{2}{|c|}{$\begin{array}{l}\text { Ukupna } \\
\text { prirodna promjena } \\
\text { između dva popisa }^{2}\end{array}$} & \multicolumn{2}{|c|}{$\begin{array}{l}\text { Migracijska bilanca } \\
\text { između dva popisa }\end{array}$} & \multirow{2}{*}{$\begin{array}{l}\text { Tip općega } \\
\text { kretanja } \\
\text { stanovništva } \\
\text { između } \\
\text { dva popisa }\end{array}$} \\
\hline & & $\begin{array}{l}\text { Apso- } \\
\text { lutna }\end{array}$ & $\begin{array}{l}\text { Rela- } \\
\text { tivna } \\
(\%)\end{array}$ & $\begin{array}{l}\text { Apso- } \\
\text { lutna }\end{array}$ & $\begin{array}{l}\text { Rela- } \\
\text { tivna } \\
(\%)\end{array}$ & $\begin{array}{l}\text { Apso- } \\
\text { lutna }\end{array}$ & $\begin{array}{l}\text { Rela- } \\
\text { tivna } \\
(\%)\end{array}$ & \\
\hline \multirow[t]{2}{*}{ 1948.-1953. } & 3.779 .858 & & & & & & & \\
\hline & 3.936 .022 & 156.164 & 4,13 & 218.101 & 5,77 & -61.937 & $-1,64$ & $\mathrm{E} 1$ \\
\hline \multirow[t]{2}{*}{ 1953.-1961. } & 3.936 .022 & & & & & & & \\
\hline & 4.159 .696 & 223.674 & 5,68 & 334.081 & 8,49 & -110.407 & $-2,81$ & $\mathrm{E} 1$ \\
\hline \multirow[t]{2}{*}{ 1961.-1971. } & 4.159 .696 & & & & & & & \\
\hline & 4.426 .221 & 266.525 & 6,41 & 269.480 & 6,48 & -2.955 & $-0,07$ & E1 \\
\hline \multirow[t]{2}{*}{ 1971.-1981. } & 4.426 .221 & & & & & & & \\
\hline & 4.601 .469 & 175.248 & 3,96 & 207.324 & 4,68 & -32.076 & $-0,72$ & E1 \\
\hline 1981.-1991. & $\begin{array}{l}4.601 .4693 \\
4.784 .265\end{array}$ & 182.796 & 3,97 & 90.544 & 1,97 & 92.252 & 2,00 & I1 \\
\hline \multirow[t]{2}{*}{ 1991.-2001. } & 4.784 .265 & & & & & & & \\
\hline & 4.492 .0494 & -292.216 & $-6,11$ & -23.171 & $-0,48$ & -269.045 & $-5,62$ & $\mathrm{E} 4$ \\
\hline \multirow[t]{2}{*}{ 2001.-2011. } & 4.437 .460 & & & & & & & \\
\hline & $4.290 .612^{5}$ & -146.848 & $-3,31$ & -96.375 & $-2,17$ & -50.473 & $-1,14$ & $\mathrm{E} 4$ \\
\hline
\end{tabular}

1 Ukupni broj stanovnika sveden na današnji teritorij.

2 Prirodni prirast procijenjen je za teritorij pripojen u popisu 1948. i 1953. godine, a ukupni prirodni prirast zbrojen je po kalendarskim godinama, a ne prema kritičnim momentima popisivanja stanovništva.

3 Kad bi se npr. ukupno stanovništvo svelo samo na rezidencijalno, međupopisna bi promjena iznosila 107910 stanovnika, prirodna bi bila 74503 stanovnika, a migracijska bilanca 33407 stanovnika. Tip općega kretanja stanovništva ostao bi isti.

4 Ukupno stanovništvo 2001. prema definiciji ukupnoga stanovništva popisa 1991. godine.

5 Prvi rezultati po naseljima popisa 2011. godine.

Izvor: Statistički ljetopis Republike Hrvatske 2009., Državni zavod za statistiku, Zagreb, 2009.; Statistička izvješća 1441: Popis stanovništva, kućanstava i stanova 2011. (prvi rezultati po naseljima), Državni zavod za statistiku, Zagreb.

- Poznato je da je Hrvatska u svim međupopisnim razdobljima od 1948. do 1981. godine imala emigracijski E1 tip op- 
DRUŠ. ISTRAŽ. ZAGREB GOD. 21 (2012), BR. 3 (117)

STR. 693-713

ŠTERC, $\mathrm{S}$ KOMUŠANAC, M.: NEIZVJESNA tivne, s tim da je ukupno prirodno kretanje bilo veće od popisom konstatiranoga porasta ukupnoga stanovništva. Tzv. gruba migracijska bilanca bila je, naravno, negativna i ukupno je u razdoblju iznosila više od 200000 stanovnika (točnije: 207375 stanovnika). Istodobno je prirodnim putem stanovništvo trebalo porasti za 1028986 stanovnika, koliko je iznosio prirodni prirast zabilježen u publikacijama vitalne statistike, ali nije, jer je kroz vanjsku emigraciju izgubljeno više od 200000 stanovnika, što ne znači da je to bila ukupna vanjska migracijska negativna bilanca. Pretpostavlja se da je osim tih 200000 osoba, koje čine smanjenje rasta Hrvatske prirodnim putem, $\mathrm{Hr}$ vatsku dodatno $\mathrm{u}$ istom razdoblju napustilo iseljavanjem još gotovo 250000 stanovnika i sve ju je to polako i sigurno vodilo primarno prema prirodnom padu, pa starenju ukupne populacije i svima ostalim demografskim negativnostima. $S$ obzirom na gospodarski razvoj Hrvatske u odnosu na druge dijelove bivše zajednice, Hrvatska je prema osnovnim zakonitostima migriranja trebala imati pozitivnu migracijsku bilancu, ali nije, i bila je to najava budućih negativnih trendova i opće negativne demografske slike nakon 1981. godine. Iseljavanje iz Hrvatske nakon Drugoga svjetskog rata nisu uvjetovali samo gospodarski razlozi u okviru socijalističko-komunističkoga društva i gospodarstva nego i politički te tako determinirali približavanje Hrvatske izumiranju, a pokazalo se kasnije i sveopćoj demografskoj destrukciji koju je izazvala agresija na Hrvatsku. Upravo je ovo iseljavanje i depopulacija ukupnoga stanovništva u prvim poslijeratnim popisima (utjecaj ratova) zaustavilo standardni demografski razvoj Hrvatske po teoriji demografske tranzicije (H1). ${ }^{4}$

- Ključna i radikalna promjena u sljedećem međupopisnom razdoblju od 1981. do 1991. godine dogodila se s prirodnim prirastom, koji je smanjen $\mathrm{u}$ odnosu na prethodno međupopisno razdoblje za čak $57 \%$. Sve je to bila posljedica rečenog u prethodnoj točki, ali i čitavoga niza ostalih neposrednih i posrednih faktora tadašnjega stagnirajućeg društva i gospodarstva i nepovoljnog statusa Hrvatske u okviru bivše zajednice. Ukupno kretanje stanovništva bilo je gotovo isto kao i u prethodnom razdoblju (3,97\%), migracijska bilanca pozitivna, a tip općega kretanja stanovništva bio je I1 ili ekspanzija imigracijom, što je potpuno suprotan proces nego u prethodnim međupopisnim razdobljima. Pojavio se prvi put, a nadamo se ne i posljednji, jer je on pretpostavka za revitalizaciju ukupnoga stanovništva, ali se na današnjem stupnju demografskog razvoja Hrvatske ne može pojaviti više sam od sebe bez ozbiljnije populacijske politike i gospodarskog razvoja. Pojavio se primarno zbog izrazita smanjivanja ukupnoga prirodnog prirasta i, naravno, zbog unutrašnjega preselja- 
DRUŠ. ISTRAŽ. ZAGREB GOD. 21 (2012) BR. 3 (117)

STR. 693-713

ŠTERC, $\mathrm{S}$. KOMUŠANAC, M. NEIZVJESNA... vanja stanovništva (unutar bivše zajednice) prema razvijenijoj republici i obali, ali i preseljavanja Hrvata prema matičnoj populaciji.

- U sljedećem međupopisnom razdoblju od 1991. do 2001. godine dogodile su se najradikalnije promjene, dijelom kao nastavak očekivanih procesa iz prethodnog razdoblja, a najviše kao posljedica agresije na Hrvatsku. Izrazit trend smanjivanja prirodnoga kretanja nastavio se, pa se već u prvoj godini razdoblja (1991.) pojavio prirodni pad i traje sa sve većim intenzitetom sve do danas. Njega su samo ubrzali posredni i neposredni ratni gubici, a s obzirom na to da se pojavio već na početku razdoblja, nisu bili presudni za smjer trenda. Ovime se posebno potvrđuje da ekspanzija imigracijom iz prethodnog razdoblja nije gotovo utjecala na prirodno kretanje stanovništva Hrvatske niti je pomladila ukupnu populaciju i stvarala osnovu za revitalizaciju. Tip općega kretanja bio je E4 ili izumiranje stanovništva uvjetovano prije svega velikim iseljavanjem stanovništva iz Hrvatske zbog agresije i oslobađanja okupiranih dijelova Hrvatske (gotovo 270000 stanovnika). U tom je razdoblju Hrvatska zbrinula velik broj Hrvata i ostaloga stanovništva iz svih dijelova bivše zajednice, a najviše iz Bosne i Hercegovine, dok je istodobno Hrvatsku napustio velik broj Srba (Šterc i Pokos, 1993.; Živić, 1999.; Živić i Pokos, 2004.).

- Svi su trendovi i pokazatelji iz prethodnoga međupopisnog razdoblja upućivali na izumiranje ukupnoga stanovništva u Hrvatskoj od 2001. do 2011. godine, pa su se prvi rezultati popisa stanovništva s nestrpljenjem očekivali. Potvrdilo se ono što smo očekivali, s tom razlikom što nije očekivana takva depopulacija (Tablica 1). Hrvatska ima oko 150000 stanovnika manje nego 2001. godine, a po prirodnom padu u istom razdoblju mogla je imati oko 100000 manje. Pojava apsolutno i relativno velike negativne vanjske migracijske bilance (oko $50 \%$ prirodnog pada) ne može se opravdati ikakvom promjenom definicije stalnoga stanovništva ili bilo kojim drugim tehničkim razlozima. Hrvatska je demografska slika odraz svih zbivanja u prošlosti, a izumiranje ukupnoga stanovništva potvrda je svih naših negativnih pretpostavki o neizvjesnoj demografskoj budućnosti i razdjelnici između trajnog izumiranja i supstitucije te moguće revitalizacije stanovništva (H2).

\section{STARENJE STANOVNIŠTVA}

Starenje ukupnoga stanovništva logična je i očekivana posljedica svih negativnih procesa u promatranom razdoblju vezanih uza stalno smanjivanje prirodnog rasta, nataliteta i reprodukcije, pojavu prirodnog pada i negativne bilance vanjske migracije i izumiranja kao tipa općega kretanja stanovništva (Tablica 2). 


\begin{tabular}{lrrrll}
\hline & \multicolumn{4}{c}{ Udio stanovništva u \% } \\
\cline { 2 - 5 } $\begin{array}{l}\text { Popisne } \\
\text { godine }\end{array}$ & Ukupno & $\begin{array}{r}\text { Mlado } \\
0-19\end{array}$ & $\begin{array}{r}\text { Zrelo } \\
20-59\end{array}$ & $\begin{array}{r}\text { Staro } \\
\geq 60\end{array}$ & $\begin{array}{l}\text { Tip dobnoga } \\
\text { sastava stanovništva }\end{array}$ \\
\hline $1991 .{ }^{1}$ & 100,00 & 26,18 & 54,86 & 17,45 & Starost \\
2001.2 & 100,00 & 23,74 & 54,30 & 21,53 & Duboka starost \\
$2008 .{ }^{3}$ & 100,00 & 21,34 & 56,22 & 22,44 & Duboka starost \\
\hline
\end{tabular}

1 Nepoznato s udjelom $1,51 \%$

${ }^{2}$ Nepoznato s udjelom $0,43 \%$

3 Procjena na dan 30. 6. 2008. godine Državnog zavoda za statistiku

4 Prema tipizaciji (Šterc, 1992.)

Izvor: Kao i za Tablicu 1.

(1) TABLICA 2

Tipovi dobnoga sastava stanovništva Republike Hrvatske 1991., 2001. i 2008 godine
Pokazatelji starosti ukupne populacije kroz odnos mladoga i staroga stanovništva u tri promatrane godine samo su još jedan u nizu pokazatelja koji potvrđuju opću negativnost hrvatske demografske slike. Na početku devedesetih Hrvatska je bila u tipu dobnoga sastava starost, a već 2001 . godine u dubokoj starosti s gotovo izjednačenim udjelima mladoga i staroga stanovništva u ukupnom.

Takvo intenzivno starenje Hrvatske unutar samo jednoga međupopisnog razdoblja, primarno uvjetovano negativnim trendovima svih osnovnih demografskih pokazatelja u dužem prethodnom razdoblju, a sekundarno intenzivirano agresijom na Hrvatsku, uz pojavu negativne migracijske bilance vanjske migracije, potvrđuje, najavljuje, usmjerava, gotovo bismo rekli determinira proces starenja i nakon 2001. godine. Projekcije za 2008. godinu dobnoga sastava stanovništva to jasno i pokazuju, jer se prvi put dogodilo da je udio staroga stanovništva (starijeg od 60 godina) veći od udjela mladoga stanovništva (mlađeg od 20 godina) i da je stanovništvo Hrvatske zapravo već na pragu izrazito duboke starosti dobnoga sastava. Promatrajući društvo i prostor Hrvatske u cjelini, bez ulaženja u razmatranje osnovnih parametara, trendova i sastava stanovništva, situacija se takvom ne čini, međutim poznavajući svu suptilnost problematike, uzročno-posljedične relacije, osnovne zakonitosti prostorno demografskih sadržaja, procesa, veza i odnosa može se zaključiti da je ona mnogo teža nego što to čak i podaci pokazuju. Pretpostavka je da će već u popisu stanovništva iz 2011. godine Hrvatska ući u tip izrazito duboka starost, pa želi li se očuvati najveća strateška vrijednost svakoga prostora - tako onda i hrvatskoga - morat će se pokrenuti ključni, odlučni, jasni ... planovi, projekti i strategije vezane uz demografsku revitalizaciju.

\section{SUPSTITUCIJA STANOVNIŠTVA}


DRUŠ. ISTRAŽ. ZAGREB GOD. 21 (2012)

BR. 3 (117)

STR. 693-713

ŠTERC, $\mathrm{S}$.

KOMUŠANAC, M.: NEIZVJESNA. troliranja prostora i njegovih bogatstava, pri čemu domicilno i u pravilu drugačije etničko i plemensko stanovništvo nije predstavljalo vrijednost nego prijetnju ostvarivanja ciljeva. Prepuna je povijest takvih primjera i primarno su stradavale male ili manje populacije i one koje su egzistirale u prostoru s važnim prirodnim bogatstvima ili pak prostorima od strateškoga značenja za kontrolu širega prostora, njegovih koridora, ključnih točaka, povoljnih geografskih obilježja za razvoj civilizacija i slično. Hrvatsku su povijest od dolaska Hrvata na Jadran usmjeravale i pratile stalne težnje izbijanja drugih naroda na to toplo more i bogatu obalu te stalna borba Hrvata za očuvanje upravo jadranske fasade. Ne elaborirajući ovdje ranija i poodmakla vremena, razmotrimo samo u tom kontekstu razdoblje od hrvatskog osamostaljenja, u kojem se u hrvatskom prostoru dogodila atipična supstitucija stanovništva i u kojem se stvaraju demografske pretpostavke za klasičnu, mirnu i puzajuću supstituciju. Umjesto relativno malobrojne hrvatske populacije na strateški važnom i civilizacijski vrijednom prostoru, primarno mediteranskih obilježja, s vrlo dubokim izvandržavnim kontinentalnim zaleđem nikad sređenih političkih prilika i odnosa, supstitucijom bi tim prostorom mogli ovladati drugi.

Između Drugoga svjetskog rata i osamostaljenja Hrvatske, pa potom i nakon agresije na nju, migracije stanovništva u Hrvatsku i iz nje bile su vrlo specifične i po smjerovima i po intenzitetu te su pokazivale zapravo početnu fazu supstitucije stanovništva u razdoblju do osamostaljenja i specifičnu supstituciju nakon osamostaljenja izazvanu agresijom na Hrvatsku.

- Već je u poglavlju o izumiranju stanovništva potvrđeno i objašnjeno da je nakon Drugoga svjetskog rata u svim međupopisnim razdobljima do 1981. godine Hrvatska jedina od svih sastavnica bivše zajednice imala emigraciju kao tip općega kretanja stanovništva, iako je kao razvijenija (uz Sloveniju) primala stanovništvo iz ostalih republika i pokrajina te imala unutrašnju pozitivnu migracijsku bilancu. Dakle, više je stanovništva uselilo u Hrvatsku iz ostalih dijelova bivše zajednice nego što se iz Hrvatske iselilo u istom smjeru, ukupno je stanovništvo poraslo manje nego što je trebalo po prirodnom prirastu i vanjska je migracija (iseljeni iz Hrvatske u inozemstvo izvan teritorija bivše zajednice) imala negativnu bilancu. Proces je pokazivao tzv. puzajuću supstituciju: jedni su se iseljavali izvan Hrvatske i istodobno izvan bivše zajednice, a drugi su se useljavali u nju s vanjskog teritorija, ali s teritorija u okviru bivše zajednice. Prvi su bili pretežito Hrvati, koji su se zbog gospodarskih i političkih razloga iseljavali iz Hrvatske prema europskim razvijenim državama i u obje Amerike, a drugi pretežito Srbi, koji su se useljavali u Hrvatsku i Hrvati koji su se useljavali iz ostalih republika i pokrajina na 
DRUŠ. ISTRAŽ. ZAGREB GOD. 21 (2012), BR. $3(117)$

STR. 693-713

ŠTERC, S., KOMUŠANAC, M.: NEIZVJESNA... teritorij Hrvatske, odnosno teritorij matične populacije. Takvim je useljavanjima u Hrvatskoj, ali i nekim drugim nedemografskim razlozima, stalno povećavan apsolutni broj Srba i relativan udio "Jugoslavena" u ukupnom stanovništvu Hrvatske. Puzajuća supstitucija stanovništva u Hrvatskoj prekinuta je agresijom na početku devedesetih.

- Napad na Hrvatsku pokrenuo je velika preseljavanja stanovništva, izazvao brojne prognaničke, izbjegličke i preseljeničke valove i determinirao prisilnu atipičnu supstituciju stanovništva apsolutno i relativno velikih razmjera, kao i redistribuciju stanovništva unutar Hrvatske. Procjenjuje se da je više od 600000 stanovnika promijenilo prebivalište iz Hrvatske i u Hrvatsku te da je unutar Hrvatske više od 500000 osoba napustilo svoje domove i zbrinuto na drugom mjestu $u$ Hrvatskoj. Sve je to bila posljedica napada na Hrvatsku i sva se preseljavanja smatraju prisilnima, pokrenuta srbijanskom agresijom i težnjom za kontrolom dijela prostora i izlaska na hrvatsku jadransku obalu. Krajnji je rezultat atipična supstitucija stanovništva, promatrana s historijsko-geografskog aspekta, $\mathrm{u}$ kojoj dolazi do promjene stanovništva tako da se $\mathrm{u} \mathrm{Hr}-$ vatskoj bitno smanjio apsolutan i relativan broj etničkih pripadnika agresora, a povećao napadnute populacije. Problem je mnogo složeniji i za sobom vuče čitav niz općedruštvenih i političkih konotacija, koje će se ubuduće razmatrati u nizu radova.

- Nakon razdoblja izumiranja stanovništva od 1991. do 2001. i njegova nastavka od 2001. do 2011. godine (iako su optimisti i svi oni koji ne istražuju demografsku sliku Hrvatske očekivali moguću vrlo slabu regeneraciju stanovništva imigracijom od 2001. do 2011. godine), izrazito velik prirodni pad, izrazito duboka starost ukupnoga stanovništva i pojava negativne vanjske migracijske bilance potvrđuju uvjete za novo razdoblje puzajuće supstitucije stanovništva Hrvatske. Dodatno to potenciraju gospodarska recesija, velika nezaposlenost, nestabilnost društva i svih sustava u njemu, što je, uostalom, i prostorna logika i neumitnost svih atraktivnih prostora, pa je lako predvidjeti da će Hrvati izumirati (10 000 i više osoba na godinu) i ponovo se iseljavati, a stanovništvo širega regionalnog i europskog prostora useljavati i postupno supstituirati autohtonu hrvatsku populaciju. Proces je tek na početku i primarno je vezan uz radnu snagu i vlasništvo nad nekretninama i tvrtkama, ali se odvija u uvjetima nepostojeće selektivne useljeničke politike (Nacionalni program demografskog razvitka, 1997.) i izostanka svake ozbiljnije populacijske koncepcije, pa je moguće i njegovo ubrzanje i intenziviranje. To si ne može dopustiti ni jedna država, koliko god liberalna i demokratska bila, jer je to pitanje od prvorazrednoga strateškog nacionalnog interesa za sve i svi su u tome konzerva- 
tivni. Supstitucija stanovništva u ovom je razdoblju najveća opasnost za opstanak Hrvatske.

\section{MOGUĆNOST REVITALIZACIJE}

Dugoročne višemodelske is različitim hipotezama objavljene UN-ove projekcije stanovništva za Hrvatsku dovoljno su ozbiljno upozorenje Hrvatskoj i njezinoj demografskoj i ukupnoj budućnosti, u kojoj će nedostajati stanovništva, radne snage i ostalih kontingenata stanovništva u planiranju razvitka prostora, regija i manje-više svih osnovnih djelatnosti. Kako je stanovništvo temelj svih planiranja i nije obnovljivo samo po sebi, Hrvatska jednostavno mora planiranje razvoja i obnove stanovništva shvatiti kao primarni interes. Postoje u osnovi samo dva modela potencijalne revitalizacije i njihove derivacije nižeg reda veličine i značenja postavljene prema demografskim resursima i potencijalima Hrvatske u zemlji i inozemstvu. Prvi je model moguć uz stimulativnu populacijsku politiku, koja se temelji na ukupnom ili stalnom stanovništvu u zemlji, a drugi posrednom imigracijskom revitalizacijom.

\section{Revitalizacija stalnim stanovništvom}

Negativnost svih pokazatelja vezanih uz domicilnu populaciju nastavit će se i intenzivirati i ubuduće, što je hrvatska neumitnost, koja se sama po sebi sigurno neće usporiti niti zaustaviti, pa je s obzirom na strateško značenje stanovništva, odnosno ljudskih resursa i potencijala, nužno iz čitavoga niza razloga demografske procese, posebno one vezane uz reprodukciju i revitalizaciju, ciljano i funkcionalno usmjeravati. Ne ulazeći u ovom radu u detaljnu razradbu različitih i različito učinkovitih mjera populacijske politike, posebno onih razrađenih i predloženih u Nacionalnom programu demografskog razvitka (Zagreb, 1997.) i pojedinim radovima (Wertheimer-Baletić, 2005., 2007.; Friganović i Šterc, 1993.), a poznavajući osnovne pokazatelje za demografska stanja, procese i projekcije, jasno je da su ciljane mjere nužne.

Stanovništvu Hrvatske na prijelazu između duboke i izrazito duboke starosti nužno je rađanje barem na razini kraja 1980-ih, ili oko 55000 rođenih u godini, što je za gotovo 12000 rođene djece $\mathrm{u}$ godini više nego danas. ${ }^{5}$ Osnovno pitanje koje se postavlja pritom jest može li sastav stanovništva Hrvatske po dobi i spolu potencijalno biološki osiguravati rodnost na razini 55000 rođene djece u godini. Fertilni kontingent ženske populacije po procjeni 2009. godine iznosio je oko 1050000 žena između 15 i 49 godina (Statistički ljetopis 2010., DZS, Zagreb), a ukupnim starenjem populacije i smanjivanjem mladoga stanovništva, a povećavanjem staroga, u- 
DRUŠ. ISTRAŽ. ZAGREB GOD. 21 (2012), BR. $3(117)$

STR. 693-713

ŠTERC, $\mathrm{S}$., NEIZVJESNA... KOMUSSANAC, M.:

dio zreloga stanovništva (pa tako i žena u fertilnom razdoblju) zadržao se gotovo na istoj razini ili čak povećao od 20 do 34 godine (H3). Time je i biološki potencijal rađanja zadržan gotovo $\mathrm{u}$ istom okviru, pa je usprkos dugotrajnim negativnim trendovima i pokazateljima hrvatska populacija u zemlji još uvijek i još neko vrijeme revitalizacijski i resurs i potencijal $(\mathrm{H} 4){ }^{6}$

Statistički podaci potvrđuju da od oko 1150000 žena u fertilnom razdoblju danas njih $3,8 \%$ u godini rodi, a za početak obnove ili revitalizacije ukupnoga stanovništva rodnost bi trebalo povećati na $4,8 \%$. Statistički to izgleda jednostavno, lako moguće i provedivo, međutim čitav niz složenih faktora utječe na snižavanje fertiliteta (Akrap, 2011.; Akrap i Čipin, 2011.; Čipin, 2011.; Gelo i sur., 2011.), koje u hrvatskom gospodarstvu i društvu nije lako promijeniti niti umanjiti njihov utjecaj (produženje obrazovanja žena, kasnije stupanje u brak, veća zaposlenost i aktivnost žena, gospodarska nesigurnost mladih, teško rješavanje stambenih uvjeta, porast udjela samohranih majki i slično). Usprkos svemu, može se zaključiti da u Hrvatskoj demografski revitalizacijski potencijal još uvijek postoji, a hoće li, kada i uz koje uvjete revitalizacija zaista i biti moguća, ovisi o strateškim odlukama i procjenama.

\section{Revitalizacija imigracijskim stanovništvom}

Revitalizaciju stanovništva Hrvatske neselektivnom i neplanskom imigracijom kroz supstituciju stanovništva, koja mijenja osnovni prevladavajući narodnosni sastav hrvatskoga državnog teritorija, nije moguće prihvatiti iz niza strateških i ranije navedenih razloga, jer se time demografski problem prenosi na mnogo složeniji općedruštveni i na pitanje opstanka Hrvatske kao nacionalne države. To nipošto ne smije biti u Hrvatskoj ponovo zabranjena tema, jer nije ni u drugim državama liberalno-demokratskoga svijeta, a kako je preseljavanje Hrvata iz različitih razloga iz drugih dijelova bivše zajednice prema matičnoj populaciji pri kraju, klasična hrvatska dijaspora ostaje u strateškom smislu također hrvatski imigracijski revitalizacijski potencijal. Klasičnom se hrvatskom dijasporom smatraju sve osobe u prekomorskim i europskim zemljama (bez već spomenutih zemalja bivše zajednice), registrirane u statističkim službama tih zemalja, za koje se može procijeniti identifikacija s hrvatskim nacionalnim ili etničkim podrijetlom i kod kojih postoji emotivna, kulturna, sociološka, prostorna i svaka druga povezanost s hrvatskim narodnim identitetom, načinom života i temeljnim hrvatskim vrijednostima, onako kako to definira često spomenuti Nacionalni program demografskog razvitka (Zagreb, 1997.). ${ }^{7}$

Procijenjeno je (NPDR, str 30.) da takvih osoba ima oko 
DRUŠ. ISTRAŽ. ZAGREB GOD. 21 (2012)

BR. $3(117)$

STR. 693-713

ŠTERC, $\mathrm{S}$.

KOMUŠANAC, M. NEIZVJESNA ljama: SAD-u, Kanadi, zemljama Južne Amerike i Afrike, Australiji i Novom Zelandu i oko 600000 u europskim zemljama, i da će cijela ta populacija imati još neko vrijeme veću stopu reprodukcije nego potpune asimilacije u novo društvo bez postojanja osjećaja hrvatske identifikacije. Pretpostavi li se standardni feminitet fertilnoga kontingenta na razini oko 650000 žena, iako je vjerojatno nešto veći zbog mlađe i vitalnije populacije, jasno je da hrvatska populacija izvan zemlje također predstavlja objektivno postojeći revitalizacijski potencijal (H5). Njegova aktivacija u funkciji povratka dijaspore u domovinu i potencijalne revitalizacije ukupnoga stanovništva u zemlji ovisi o postavljanju strateških okvira kojim se želi kretati Hrvatska u budućnosti i jasnoj želji da očuva demografski i svekoliki hrvatski identitet.

\section{OSNOVNE PRETPOSTAVKE REVITALIZACIJE}

Već smo zaključili da revitalizacija ukupnoga stanovništva Hrvatske nije moguća sama po sebi kao nastavak demografskih trendova, nego je za to potrebna planska, strateška, programska, funkcionalna, znanstveno utemeljena i razvojno potrebna intervencija države i njezinih resornih institucija. Osnovne pretpostavke objektivno potrebne revitalizacije stanovništva Hrvatske, kojom bi se zaustavilo izumiranje i supstituiranje domicilne populacije (stalnog stanovništva u zemlji) i koje se može provesti u postojećim društvenim, političkim i gospodarskim okvirima, moguće je svesti na ove:

- Vlada Hrvatske nužno mora demografsku problematiku postaviti na razinu strateškoga nacionalnog značenja o kojem ovisi ukupni razvoj i opstanak samostalne države i očuvanje hrvatskoga teritorija i svih njegovih vrijednosti.

- Osnova svih društvenih, gospodarskih, prostornih, regionalnih i granskih planiranja morala bi biti stanovništvo, pa bi i briga o njemu bila u skladu s njegovim značenjem kao temeljem na kojem počiva svaka teritorijalna zajednica u svijetu.

- Republika Hrvatska i njezina zakonodavna i izvršna vlast ne bi smjele čekati idealno vrijeme gospodarskoga stupnja razvitka zemlje, u kojem bi se stvorili preduvjeti demografske obnove, jer takvo idealno vrijeme nikad neće postojati, nego u skladu sa strateškim značenjem i ulogom stanovništva i negativnom ukupnom demografskom slikom Hrvatske, treba odmah osmišljavati i provoditi populacijsku politiku, potrebnu za razvitak zemlje.

- Sva tri dosadašnja dokumenta vezana uz demografski razvoj Hrvatske nužno je ujediniti u jedan sa svim relevantnim parametrima i revitalizacijskim mjerama, uz prethodno formiranje vijeća za demografski razvoj, koje bi činili svi, ali svi stručnjaci te i srodne problematike, neovisno o političkoj 
DRUŠ. ISTRAŽ. ZAGREB GOD. 21 (2012), BR. $3(117)$

STR. 693-713

ŠTERC, $\mathrm{S}$ KOMUŠANAC, M.: NEIZVJESNA... pripadnosti te osobnim, ideološkim i stručno-znanstvenim različitostima.

- Svaka država s takvim demografskim problemima i posebno s tako brojnom i bogatom dijasporom ima najveću institucionalno posloženu razinu izvršne vlasti za njihovo rješavanje. Hrvatskoj treba ponovo povratak svih veza s dijasporom, njezino uključivanje $u$ sve tokove $u$ zemlji, posebno gospodarske, investicijske i privatizacijske, a za takvu ozbiljnu razinu, bitnu i za gospodarski i demografski oporavak zemlje, nužno je posebno ministarstvo. To je jedna od strateških odluka koje se očekuje.

- Prema demografskim resursima i potencijalima, $\mathrm{Hr}$ vatska se treba oslanjati na ključne mjere vezane i uz domicilnu i za iseljeničku populaciju, kombinirajući njihovu povezanost i neodvojivost, prihvaćajući pritom dijasporu kao neupitno hrvatsko bogatstvo.

- Provedbene mjere dosadašnje populacijske politike nisu u Hrvatskoj donijele očekivane rezultate, usprkos relativno i apsolutno znatnim utrošenim sredstvima iz državnoga proračuna, a slična su i iskustva drugih zemalja (Demeny, 2003.; Letablier, 2003.; Sanderson, 2011.). Zato treba radikalizirati pristup revitalizaciji ukupne populacije stimuliranjem povećanja rodnosti, dajući naknadu za svako rođeno dijete, s obzirom na to da on počinje djelovati odmah, njegovi su rezultati izravni, ne treba čekati duže razdoblje primjene i zapravo je najjednostavniji ako slijedimo iskustva i promišljanja i u drugim zemljama.

- Usprkos velikim problemima s punjenjem hrvatskoga državnog proračuna i njegovim stalnim deficitom, vrlo složenoj i teškoj gospodarskoj situaciji, velikoj nezaposlenosti te nizu drugih nepovoljnih okolnosti, navedeni model lako je razraditi i kvantificirati prema ciljanoj rodnosti od $55000 \mathrm{u}$ godini.

- Prihvaćajući njemački revitalizacijski model (Sanderson, 2011.), ali s različitim parametrima, za ciljanu rodnost $\mathrm{u}$ Hrvatskoj kojom bi se izbjegla depopulacija, izumiranje, starenje ukupne populacije i supstitucija stanovništva mora se donijeti strateška odluka o izdvajanju dijela proračunskih sredstava za tu namjenu u visini od 1,6 do 3,2\%. Uspoređujući visinu tog izdvajanja s nekim drugim strateškim financiranjem iz proračuna, a s obzirom na značenje revitalizacije ukupnoga stanovništva za Hrvatsku, smatramo da bi tu odluku Vlada Hrvatske zbog općeg interesa i budućnosti zemlje nužno trebala donijeti. Time bi se omogućilo da svako rođeno dijete dobije 5000 do 10000 eura, što smatramo bitnom egzistencijalnom i potencijalnom mjerom koja jedino može donijeti izravne i relativno brze rezultate.

- Drugi revitalizacijski model trebao bi biti vezan uz dijasporu i potencijalni fertilni kontingent ženske populacije, 
DRUŠ. ISTRAŽ. ZAGREB GOD. 21 (2012)

BR. $3(117)$

STR. 693-713

ŠTERC, $\mathrm{S}$. KOMUŠANAC, M. NEIZVJESNA...

\section{ZAKLJUČAK}

\section{BILJEŠKE}

koja čini po procjenama čak $72,7 \%$ istoga domicilnog kontingenta. Međutim, ovaj model morao bi biti vezan i uz povratak u Hrvatsku i uz povećanje rodnosti povratničke populacije. Stimulirala bi se na isti način kao po prethodnom modelu rodnost povratnika uz njihov ostanak u Hrvatskoj u dužem razdoblju, koje se može definirati za razdoblje od 10 godina. Pretpostavka je da bi se na taj način rodnost potencijalno mogla povećati za dodatnih 10000 , čime bi se dostigla rodnost ukupnoga stanovništva Hrvatske s početka 1980-ih godina i time pokrenula revitalizacija ukupnoga stanovništva te zaustavili svi negativni trendovi i pokazatelji. Uz iste parametre stimuliranja iz prethodnoga modela od 5000 do 10000 eura, iz proračuna bi se dodatno izdvojilo još između 0,31 i 0,62\% sredstava.

- Kombinacijom standardnoga i imigracijsko-povratničkoga revitalizacijskog modela, uz prihvaćanje strateškoga značenja demografske problematike za opstanak hrvatske države i naroda, postigli bi se relativno brzo planirani i za gospodarski i opći razvoj potrebni rezultati, bez posebnih aktivnosti raznih tijela i institucija, usporavanja skupoga, velikog i tromog administrativnog sustava i silnih sterilnih rasprava o potrebnosti postupanja. Treba samo shvatiti strateško značenje projekta i donijeti odluku u korist opstanka i razvitka Republike Hrvatske.

1. Demografski se razvoj Hrvatske ne može objasniti samo općom teorijom demografske tranzicije nego primarno nizom posebnih čimbenika u okviru prostorne i povijesne uvjetovanosti.

2. Neprijeporno izumiranje stanovništva Hrvatske stvara pretpostavku za prostornu supstituciju njezina stanovništva.

3. Fertilni kontingent ženskoga stanovništva još je uvijek i još će kraće vrijeme biti hrvatski reprodukcijski demografski potencijal.

4. Revitalizacijski modeli stanovništva Hrvatske još se uvijek mogu i trebaju postavljati prema stalnom stanovništvu u zemlji.

5. Hrvatska je dijaspora moguća revitalizacijska osnova strategije demografskog razvoja Hrvatske.

${ }^{1}$ Iako se radi samo o prvim rezultatima popisa stanovništva iz 2011. godine, koji će u konačnici biti korigirani tzv. namjerom odsutnosti i prisutnosti $u$ naselju i diplomatskom populacijom, u osnovi ostaje definicija uobičajenoga stanovništva prema uobičajenom mjestu stanovanja kao ukupnoga i stalnoga stanovništva. Nikakvo kasnije friziranje podataka neće moći popraviti ukupnu sliku depopulacije u 
DRUŠ. ISTRAŽ. ZAGREB GOD. 21 (2012), BR. $3(117)$

STR. 693-713

ŠTERC, $\mathrm{S}$. KOMUŠANAC, M.: NEIZVJESNA..
Hrvatskoj nakon intenzivnoga međupopisnog prirodnog pada i pojave vanjske negativne migracijske bilance $\mathrm{u}$ zadnjim godinama istog razdoblja.

2 Tipizacija općeg kretanja stanovništva u demogeografskoj je literaturi modelski razrađen sustav razmatranja odnosa međupopisne promjene ukupnoga stanovništva i prirodnoga kretanja stanovništva, koji rezultira tzv. grubom migracijskom bilancom i tipizacijom imigracije i emigracije stanovništva, a sadržaj je obveznoga obrazovnog sustava.

3 Prikazani podaci u tablici ostavljeni su u izvornoj statističkoj formi, usprkos promjeni definicije stalnoga stanovništva, posebno s prvim popisom što ga je samostalno provela Hrvatska (jedan od autora članka recenzent je tadašnjeg zakona o stanovništvu i autor definicije stalnog stanovništva) i promjene vođenja vitalne statistike 1998. godine. Svođenjem svih podataka u prošlim popisima na rezidencijalno stanovništvo i razdvajanje vitalnih događaja u Hrvatskoj i izvan nje i formalno bi isključio demografski potencijal koji nam je ovdje primaran.

${ }^{4}$ Najjednostavnije je sve objasniti gotovo funkcionalnom korelacijom gospodarskih i demografskih pokazatelja i trendova, okvirnim kontingentima i općim razvojem. Međutim, Hrvatska je u tome posebna. Jedina je imala depopulaciju nakon svih ratova u okruženju, jedina je kao razvijeniji prostor imala emigraciju ukupnoga stanovništva između popisa i mogla je prema svim usporednim pokazateljima imati stope demografskog rasta kao npr. Slovenija ili Srbija do 1981. godine. Mogla je imati oko 5 milijuna stanovnika u prvoj varijanti ili 6,4 milijuna u drugoj već 1981. godine (Šterc, 1991.). Mogla je, ali nije. I zato je danas po pokazateljima i trendovima gotovo kao Njemačka (Eurostat, 2010.) ili odmah iza nje i ima završenu demografsku tranziciju. Gospodarski to nije logično, znanstveno i politički je "opravdavano", demografska je prošlost izgubljena, a mi ne želimo da bude i budućnost, koliko god to ekonomisti i globalni planeri željeli.

${ }^{5}$ Rodnost hrvatske populacije u zemlji od 55000 na godinu donja je moguća granica potencijalne revitalizacije, s obzirom na pojavu negativne vanjske migracijske bilance zadnjih godina, primarno starosno-biološki uvjetovanoga mortaliteta i stimulativno mogućega rađanja u potencijalnom hrvatskom demografskom okviru u zemlji. Autorska je to procjena na osnovi praćenja dinamičkih srednjih vrijednosti osnovnih pokazatelja nakon 1960. godine, koja bi omogućila prirodni prirast stanovništva, moguće zaustavljanje depopulacije, iako još uvijek neodgovarajuće stope reprodukcije i ukupnoga fertiliteta. Bio bi to prvi korak ili razdoblje (barem u 10 godina) prema potencijalnoj revitalizaciji.

6 Statistički podaci potvrđuju od 1991. do 2009. godine smanjenje fertilnoga ženskog kontingenta sa 1149407 u 1991. godini na 1080121 u 2001. godini i 1038600 u 2009. godini (apsolutno 110807 žena, a relativno za 9,6\%), dok je istodobno rodnost smanjena za 19,5\%. No razmotrimo samo kontingent ženskoga stanovništva od 20 do 29 godina, u kojoj je moguć veliki potencijal rađanja. Taj je kontingent isti 2009. i 2001. godine, a 2009. rođeno je 3584 djece više nego 2001. 
DRUŠ. ISTRAŽ. ZAGREB GOD. 21 (2012) BR. 3 (117)

STR. 693-713

ŠTERC, $\mathrm{S}$. KOMUŚANAC, M.: NEIZVJESNA...

\section{LITERATURA}

godine (8,7\% više). Petogodišnja dobna skupina od 30 do 34 godine ima čak više žena 2009. nego 2001. godine (u njoj je zadnjih godina prevladavajuće rađanje u Hrvatskoj) itd. itd. Jasno je da će se ubuduće smanjivati ukupni fertilni kontingent žena, poštujući sve faktore koji u društvu i prostoru djeluju na to, no jasno je i vidljivo da potencijal za rađanje još uvijek postoji, da može reagirati na stimulativne mjere i da znanstveno dokazivanje nemogućnosti povećanja rodnosti u domicilnoj populaciji isključuje strateško značenje toga pitanja. To, istina, neće potrajati dugo, po našoj procjeni možda samo u ovom međupopisnom razdoblju.

7 Osim NPDR-a iz 1996. godine, postoji i Nacionalna populacijska politika iz 2006. godine. Razlika je, jasno, u vremenu, ali i u osnovnom pristupu problematici. Prakticizam nacionalne politike iz 2006. godine $u$ presloženom sustavu brojnih ministarstava, agencija, ureda i raznorodnih predstavnika u vijeću nije mogao nadoknaditi strateško značenje i pristup u Programu. Naš je izbor Program i procjene u njemu, iz osnovnog razloga što nam je primaran potencijal, mogućnost, a ne statistički resursi registrirani popisima stanovništva imigracijskih zemalja. Svi će noviji podaci iz kanadskih, američkih ili njemačkih popisa stanovništva registrirati iz brojnih razloga više nego upola manje pripadnika hrvatske više ili manje asimilirane manjine. Mi smo se priklonili procjenama iz Programa stoga što je moguće procijeniti po standardnoj stopi obnove i asimilacije stanovništava potencijalnu reprodukciju iseljenoga stanovništva iz $\mathrm{Hr}$ vatske, primarno u 20. stoljeću, a kako se radi o potencijalu, a ne o resursu, smatramo procjene iz Programa relevantnim potencijalom.

Akrap, A. (2011.), Sektor zaposlenosti žena i fertilitet u Hrvatskoj. Društvena istraživanja, 20 (1): 3-23. doi:10.5559/di.20.1.01

Akrap, A. i Čipin, I. (2011.), Usklađivanje poslovnog i obiteljskog života u Hrvatskoj: utjecaj na fertilitet. Društvena istraživanja, 20 (1): 47-68. doi:10.5559/di.20.1.03

Akrap, A., Čipin, I., Pokos, N., Ridzak, T. i Živić, D. (2003.), Činitelji demografskih kretanja u Republici Hrvatskoj, Zagreb, Državni zavod za zaštitu obitelji, materinstva i mladeži.

Čipin, I. (2011.), Obrazovanje i fertilitet zaposlenih žena u Hrvatskoj. Društvena istraživanja, 20 (1): 25-46. doi:10.5559/di.20.1.02

Demeny, P. (2003.), Population Policy Dilemmas in Europe at the Dawn of the Twenty-First Century. Population and Development Review, 29 (1): 1-28. doi:10.1111/j.1728-4457.2003.00001.x

Friganović, M. (1966.), O metodi geografskog proučavanja stanovništva. Geografski glasnik, 28 (1): 129-131.

Friganović, M. (1983.), Teorijski okvir i empirijski pristup demografskom razvoju i problemima SR Hrvatske 1971.-1981. Radovi, 17-18: 21-38.

Friganović, M. (1984.), Egzodusna područja (ne) razvijenost i populacijska politika u SR Hrvatskoj. Radovi, 19: 29-38.

Friganović, M. A. i Šterc, S. (1993.), Demogeografski razvoj i populacijska politika Republike Hrvatske. Društvena istraživanja, 2 (1): 151-165. 
DRUŠ. ISTRAŽ. ZAGREB GOD. 21 (2012), BR. 3 (117),

STR. 693-713

ŠTERC, $\mathrm{S}$ KOMUŠANAC, M.: NEIZVJESNA
Gelo, J. (1999.), Ratni učinci na promjene demografskih struktura u Hrvatskoj. Društvena istraživanja, 8 (5-6): 735-749.

Gelo, J. (2004.), Kretanje broja rezidencionalnog (boravećeg) stanovništva Hrvatske u 20. stoljeću. Društvena istraživanja, 13 (4-5): 653- 673.

Gelo, J., Smolić, Š. i Strmota, M. (2011.), Sociodemografske odrednice zaposlenosti žena u Hrvatskoj. Društvena istraživanja, 20 (1): 69-88. doi:10.5559/di.20.1.04

Gelo, J., Akrap, A. i Čipin, I. (2005.), Temeljne značajke demografskog razvoja Hrvatske (bilanca 20. stoljeća), Ministarstvo obitelji, branitelja i međugeneracijske solidarnosti, Zagreb.

Grizelj, M. (2005.), Projekcije stanovništva Hrvatske do kraja stoljeća. U: Stanovništvo Hrvatske - dosadašnji razvoj i perspektive (str. 331-352), Zagreb, Institut društvenih znanosti Ivo Pilar.

Lajić, I. (1995.), Demografski razvitak Hrvatske u razdoblju od 1991. do 1994. Revija za sociologiju, 26 (1-2): 55-64.

Lajić, I. i Šterc, S. (1990.a), Migracijska bilanca općina Hrvatske u razdoblju 1971. do 1981. Sociologija sela, 22 (107/108): 19-33.

Lajić, I. i Šterc, S. (1990.b), Emigracijske i imigracijske općine. U: Demografski faktori razvoja Hrvatske (str. 227-255), Zagreb, IDIS.

Letablier, M. (2003.), Fertility and Family Policies in France. Journal of Population and Social Security (Population), 1: 245-261.

Mrđen, S. (2005.), Projekcije stanovništva Hrvatske do 2031. godine. U: Stanovništvo Hrvatske - dosadašnji razvoj i perspektive (str. 315-330), Zagreb, Institut društvenih znanosti Ivo Pilar.

Nacionalni program demografskog razvitka (1997.), Ministarstvo razvitka i obnove, Zagreb.

Nejašmić, I. i Mišetić, R. (2004.), Buduće kretanje broja stanovnika Hrvatske: projekcija 2001.-2031. Društvena istraživanja, 13 (4-5): 751-776.

Oliviera-Roca, M. (1990.), Unutrašnja migracija. U: Demografski faktori razvoja Hrvatske (str. 63-93), Zagreb, IDIS.

Pejnović, D. (2004.), Depopulacija županija i disparitet u regionalnom razvoju Hrvatske. Društvena istraživanja, 13 (4-5): 701-726.

Sanderson, W. (2011.), Low Fertility and Population Aging in Germany and Japan: Prospects and Policies. U: Fertility and Public Policy: How to Reverse the Trend of Declining Birth Rates (str. 51-80), Cambridge, MIT Press.

Šterc, S. (1984.), Tipovi općeg kretanja stanovništva nedovoljno razvijenih općina SR Hrvatske. Ekonomski pregled, 35 (11-12): 547- 563.

Šterc, S. (1986.), O suvremenom geografskom objektu istraživanja s posebnim osvrtom na demogeografiju. Geografski glasnik, 48: 99-121.

Šterc, S. (1991.), The General Demographic Cross Section of the Republic of Croatia. Geographical Papers, 8: 1-38.

Šterc, S. (1992.), Prostorni i demografski aspekti revitalizacije ruralnih naselja u Hrvatskoj. Društvena istraživanja, 1 (1): 127-157.

Šterc, S. i Crkvenčić, I. (1996.), The Population of Croatia. GeoJournal, 38 (4): 417-424. 
DRUŠ. ISTRAŽ. ZAGREB GOD. 21 (2012)

BR. 3 (117),

STR. $693-713$

ŠTERC, $\mathrm{S}$. KOMUŠANAC, M.: NEIZVJESNA...
Šterc, S. i Pokos, N. (1993.), Demografski uzroci i posljedice rata protiv Hrvatske. Društvena istraživanja, 2 (2-3): 305-333.

Wertheimer-Baletić, A. (1982.), Demografska tranzicija kao svjetski proces. Ekonomska revija, 3-4: 271-280.

Wertheimer-Baletić, A. (1989.), Tendencije u razvitku stanovništva SR Hrvatske. Ekonomski pregled, 40 (5-6): 231-250.

Wertheimer-Baletić, A. (1992.a), Posttranzicijska etapa u razvoju stanovništva (opća i metodološka razmatranja). Ekonomski pregled, 10-11-12: 643-656.

Wertheimer-Baletić, A. (1992.b), Demografske promjene i globalni demografski procesi u Hrvatskoj u poslijeratnom razdoblju. Encyclopedia moderna, god. 13, 2 (38): 238-251.

Wertheimer-Baletić, A. (2000.), Populacijska politika u zemljama s posttranzicijskim obilježjima razvoja stanovništva. Rad HAZU, 480: 163-181.

Wertheimer-Baletić, A. (2004.), Depopulacija i starenje stanovništva temeljni demografski procesi u Hrvatskoj. Društvena istraživanja, 13 (4-5): 631-651.

Wertheimer-Baletić, A. (2005.), Starting Points for Pronatal Population Policy in Croatia. Zbornik radova Ekonomskog fakulteta u Rijeci: časopis za ekonomsku teoriju i praksu, 23 (2): 217-236.

Wertheimer-Baletić, A. (2007.), Depopulacija, starenje stanovništva i populacijska politika u Hrvatskoj. Rad HAZU, 45: 73-120.

Živić, D. (2003.), Demografske odrednice i posljedice starenja stanovništva Hrvatske. Revija za socijalnu politiku, 10 (3-4): 317-319.

Živić, D. (2008.), Demografske prilike u Hrvatskoj početkom 1990-ih godina. Časopis za suvremenu povijest, 40 (1): 219-236.

Živić, D., Pokos, N. i Turk, I. (2005.), Basic Demographic Processes in Croatia. Hrvatski geografski glasnik, 67 (1): 27-44.

Živić, D. i Pokos, N. (2004.), Demografski gubitci tijekom domovinskog rata kao odrednica depopulacije Hrvatske (1991.-2001.). Društvena istraživanja, 13 (4-5): 727-750.

Živić, D., Pokos, N. i Mišetić, A. (ur.) (2005.), Stanovništvo Hrvatske dosadašnji razvoj i perspektive, Institut društvenih znanosti Ivo Pilar, Biblioteka Zbornici, knjiga 28, Zagreb.

\section{Uncertain Demographic Future of Croatia - Dying Out and Substitution or Revitalization of Population...?}

Stjepan ŠTERC, Monika KOMUŠANAC

Faculty of Science, Zagreb

The main objective and purpose of this study is to confirm the impossibility of revitalization without a serious, responsible and focused population policy, to assess the potential for revitalization (which still exists, despite many negative aspects of the Croatian demographic situation) and to place 
DRUŠ. ISTRAŽ. ZAGREB GOD. 21 (2012), BR. 3 (117)

STR. 693-713

ŠTERC, $\mathrm{S}$

KOMUSSANAC, M.: NEIZVJESNA the issue of demographics within the foundations of the development and survival of contemporary Croatia. All analyses have confirmed a significant negative trend in all parameters and the impossibility of stopping negative processes without a serious intervention of the State, through stimulative population policy and the participation of Croatian immigration in economic, political and revitalization processes in the country. The methodological approach within the framework of standard demographic norms is focused exclusively on basic content, processes and relationships so as to project through these factors the dramatic state Croatia is currently in. Knowledge on spatial norms developed in space by the population has been applied in particular, taking into consideration the situation on state and regional levels. The most important result of the analysis is that Croatia, despite longtime negative trends in all demographic processes, still carries demographic potential on a national level, particularly in the diaspora and has the ability, through incentives population policy, to stop the dying out and quick aging of the general population and initiate the process of its revitalization, with the aim of economic development and the development of the country's future.

Keywords: natural decrease, depopulation, aging, dying out, revitalisation 